\title{
Orbit Lymphoma
}

National Cancer Institute

\section{Source}

National Cancer Institute. Orbit Lymphoma. NCI Thesaurus. Code C6244.

A lymphoma that arises from the structures of the orbit. Representative examples

include mucosa-associated lymphoid tissue lymphoma, follicular lymphoma, and diffuse

large B-cell lymphoma. 